\title{
Technical and Economic Evaluation of Phorbol Esters Extraction from Jatropha curcas Seed Cake using Supercritical Carbon Dioxide
}

\section{Cristiane de Souza Siqueira Pereira ${ }^{{ }^{*}}$, Fernando Luiz Pelegrini Pessoa ${ }^{1}$, Simone Mendonca ${ }^{2}$, Jose Antonio de Aquino Ribeiro ${ }^{2}$ and Marisa} Fernandes Mendes ${ }^{3}$

${ }^{*}$ Technology of Chemical and Biochemical Processes, Chemistry School, Federal University of Rio de Janeiro, Brazil

${ }^{2}$ Embrapa Agroenergy, Brasilia, Brazil

${ }^{3}$ Chemical Engineering Department, Federal Rural University of Rio de Janeiro, Brazil

\begin{abstract}
Jatropha curcas plant shrub of Euphorbiaceae family is a plant whose seeds are rich in oil that can be used for biofuel production. However the seeds contain many toxic compounds which the most important ones are known as phorbol esters (PEs). This study has as aim the study of the technical and economic feasibility of the supercritical fluid for the PEs extraction present in the Jatropha seed cake. The effect of temperature $\left(40-100^{\circ} \mathrm{C}\right)$ and pressure (100-500 bar) on the phorbol yield was investigated using a central composite design methodology to determine the significance and interactions of these parameters. PEs in the extracted samples were analyzed and quantified by HPLC. The supercritical fluid extraction was effective in the recovery of PE extracted from Jatropha curcas cake varying from $23.0 \%$, at $70^{\circ} \mathrm{C}$ and 500 bar to $2.6 \%$ at $90^{\circ} \mathrm{C}$ and 160 bar. The results showed that pressure had the most significant enhancing effect on the phorbol ester yield. Simulations of phorbol ester extraction from Jatropha curcas cake were carried out using SuperPro Designer 9.0 (Intelligen, Inc) to evaluate production costs of an industrial process to treat the necessary quantity of cake. It was possible to conclude that the supercritical extraction is viable to be applied.
\end{abstract}

Keywords: Detoxification; Screw press; Design experiment; Scale-up

\section{Introduction}

Jatropha curcas L. seed, known as "pinhão-manso" in Brazil, is an important oleaginous which has received great attention in recent years due to its utilization in biodiesel production [1]. Jatropha curcas oil is usually extracted by screw presses and for every thousand of liters of Jatropha oil, around 2 tonnes of press cake are produced [2].

The cake remaining after oil extraction is rich in proteins but it also contains toxic compounds [3]. The toxicity is due to the presence of high levels of toxic and anti-nutritional components as trypsin inhibitors, lectins, saponins, phytate and PEs. Although others compounds are present, PE is the main toxic component of Jatropha curcas and the concentration of them is the parameter that limits the utilization of the protein rich pressed cake for animal nutrition [4].

The phorbol esters molecules are tetracyclic diterpenoids with a tigliane skeletal structure [5]. These authors isolated six different types of PE of Jatropha curcas and all of these compounds possess the same diterpene core, namely, 12-deoxy-16-hydroxyphorbol. These compounds present in the seeds were designated as jatropha factors $\mathrm{C} 1$, C2, C3, epimers C4, C5 and C6, with the molecular formula $\mathrm{C}_{44} \mathrm{H}_{54} \mathrm{O}_{8}$.

Different chemical, physical and biologic methods have been employed for the removal or inactivation of PEs from oil, kernel or pressed cakes in order to promote their use as a protein source for animal feed [6-10]. PEs are double-edged swords, having a lot of negative effects on human and livestock. They also possess some beneficial effects, because not all of the PEs are toxic and their activity and potency vary from one type of PE to another [11]. Many works have been studied in order to extract the PEs to add value to this by product [12-15]. The purified PEs could also be converted or transformed chemically into nontoxic compounds with beneficial activities such as the hydrolysis of 12-deoxy-16-hydroxyphorbol that results in the synthesis of 12-deoxyphorbol-13-phenyl acetate, a compound that is considered as a promising adjuvant for antiviral therapy because of its anti-HIV properties [14].

There are several studies on the detoxification of Jatropha curcas cake using organic solvents and chemical treatments, for example, hexane, methanol, petroleum ether and potassium hydroxide $[16,17]$. However, authors reveal that these techniques are not economically feasible and the multiple steps involved in the processing of the biomass up to the detoxification stage are also costly and not environment friendly. Based on this fact, the supercritical extraction process has advantages compared to conventional methods with organic solvent. This technology implies in the use of the principles of green chemistry and engineering, from process inception in the research environment to process application on a commercial scale [18]. The carbon dioxide in its supercritical state is a promising solvent due to its characteristics like inertness, non-toxicity, no flammability, non-explosiveness, and availability with high purity at low cost [19].

There are no reports in the literature concerning the extraction of PEs from Jatropha curcas cake with supercritical carbon dioxide.

*Corresponding author: Cristiane de Souza Siqueira Pereira, Technology of Chemical and Biochemical Processes, Chemistry School, Federal University of Rio de Janeiro, Brazil, Tel: +5524981240208; E-mail: crispereirauss@gmail.com

Marisa Fernandes Mendes, Chemical Engineering Department, Federal Rura University of Rio de Janeiro, Brazil, Tel: +55-21 37873742; Fax: 55-37873750; E-mail: marisamf@ufrrj.br

Received July 20, 2015; Accepted August 07, 2015; Published August 14, 2015

Citation: Pereira CSS, Pessoa FLP, Mendonca S, Ribeiro JAA, Mendes MF (2015) Technical and Economic Evaluation of Phorbol Esters Extraction from Jatropha curcas Seed Cake using Supercritical Carbon Dioxide. J Adv Chem Eng 5: 132 doi:10.4172/2090-4568.1000132

Copyright: (c) 2015 Pereira CSS, et al. This is an open-access article distributed under the terms of the Creative Commons Attribution License, which permits unrestricted use, distribution, and reproduction in any medium, provided the original author and source are credited. 
Because of the scarce of data concerning PEs extraction with supercritical $\mathrm{CO}_{2}$, this study has as aim the technical and economical evaluation of this type of extraction of PEs present in the Jatropha curcas seed cake.

\section{Materials and Methods}

\section{Materials}

Jatropha curcas seeds were kindly provided by Empresa de Pesquisa Agropecuária de Minas Gerais (EPAMIG) grown in the region of Janaúba city, located in the north of Minas Gerais state (Brazil). The Jatropha curcas press cake was obtained using a tubular radial screw press with capacity of $50 \mathrm{~kg} / \mathrm{h}$ (Brand: SCOTTECH), which provided approximately $19.6 \%$ of oil. The press cake composition was detailed in Ref. [10]. After pressing, the material was stored in a plastic bag in the refrigerator for later experiments. Liquid $\mathrm{CO}_{2}$ (99.9\% pure) was from White Martins (Rio de Janeiro, Brazil).

\section{Experimental design}

Jatropha pressed cake was submitted to the extraction process following a central composite rotational design (CCRD) with two independent variables (pressure and temperature), commonly studied in a supercritical extraction process. Table 1 shows the coded and actual levels of variables and describes the 11 experiments that were carried out. The results were statistically analyzed using a statistical program.

\section{Supercritical carbon dioxide extraction}

The supercritical fluid extraction (SFE) experiments were performed in an apparatus, built in the Applied Thermodynamics and Biofuel Laboratory at Chemical Engineering Department/ UFRRJ, consisting of a stainless steel $316 \mathrm{~S}$ extractor with $42 \mathrm{~mL}$ of capacity. The extractor contains two canvas of 260 mesh to prevent the entrainment of material. A high-pressure pump (Palm model G100), specific for pumping $\mathrm{CO}_{2}$ was responsible for the solvent feeding into the extractor. A thermostatic bath (Fisatom model) was coupled in the extractor to control the temperature and a manometer was on line installed for pressure measurement. The flowsheet of the experimental apparatus is shown in Figure 1. The same apparatus has been used in numerous studies done by the research group [20] and the experimental procedure was done in a semi-batch way. Initially, the extractor was filled with the solid material, approximately, $10 \mathrm{~g}$ of Jatropha pressed

\begin{tabular}{|c|c|c|c|c|}
\hline \multirow[t]{2}{*}{ Run } & \multicolumn{2}{|c|}{ Coded level of variables } & \multicolumn{2}{|c|}{ Actual level of variables } \\
\hline & $\begin{array}{c}\text { Temperature } \\
\text { (x1) }\end{array}$ & $\begin{array}{l}\text { Pressure } \\
\text { (x2) }\end{array}$ & $\begin{array}{c}\text { Temperature } \\
\left({ }^{\circ} \mathrm{C}\right)\end{array}$ & $\begin{array}{l}\text { Pressure } \\
\text { (Bar) }\end{array}$ \\
\hline \multicolumn{5}{|c|}{ Factorial points } \\
\hline 1 & -1 & -1 & 50 & 160 \\
\hline 2 & +1 & -1 & 90 & 160 \\
\hline 3 & -1 & +1 & 50 & 440 \\
\hline 4 & +1 & +1 & 90 & 440 \\
\hline \multicolumn{5}{|c|}{ Axial points } \\
\hline 5 & $-\alpha(-1.41)$ & 0 & 40 & 300 \\
\hline 6 & $+\alpha(+1.41)$ & 0 & 98 & 300 \\
\hline 7 & 0 & $-\alpha(-1.41)$ & 70 & 100 \\
\hline 8 & 0 & $+\alpha(+1.41)$ & 70 & 500 \\
\hline \multicolumn{5}{|c|}{ Center points } \\
\hline 9 & 0 & 0 & 70 & 300 \\
\hline 10 & 0 & 0 & 70 & 300 \\
\hline 11 & 0 & 0 & 70 & 300 \\
\hline
\end{tabular}

Table 1: Central composite rotatable design matrix applied for the supercritical fluid extraction. cake. The sampling was done using a micrometric valve, reducing the pressure, and the oily extract was recovered in a previously weighed polypropylene tube. Sampling occurred at each 10 minutes with the depressurization of the system.

The extraction yield was estimated according to equation 1 :

$$
\text { Yield }(\%)=\frac{\text { mass of extract }(g)}{\text { mass of cake }(g)} \times 100
$$

with mass of extract as the oily fraction extracted at each $10 \mathrm{~min}$ and the mass of cake was $10 \mathrm{~g}$, approximately, for all the experiments.

\section{Phorbol ester analysis}

The PEs from extracts of Jatropha cake with supercritical $\mathrm{CO}_{2}$ and from cake pressed was analyzed in Embrapa Agroenergia (Brasília, Brazil).

\section{Phorbol esters analysis from pressed cake}

The methodology used in this work was adapted from Makkar et al. [4]. It was transferred, approximately, $4 \mathrm{~g}$ of Jatropha curcas cake to cells accelerated solvent extractor (ASE 350). The samples contained in the cells were extracted with methanol using the following conditions: temperature: $60^{\circ} \mathrm{C}$; heat time: $5 \mathrm{~min}$; static time: $2 \mathrm{~min}$; number of cycles: 5; rinse volume: $150 \%$ and a purge time of $60 \mathrm{~s}$. The extracts from the ASE tubes were evaporated under vacuum in a water bath at $60^{\circ} \mathrm{C}$ (rotaevaporator). It was added $2.5 \mathrm{~mL}$ of HPLC grade methanol to the ASE tubes and it was mixed for 20 to 30 seconds. The methanolic extracts were transferred to a test tube of $10 \mathrm{~mL}$ and centrifuged at $4000 \mathrm{rpm}$ for 3 minutes. The clear supernatant was transferred to a volumetric flask of $5 \mathrm{~mL}$ with the aid of micropipette. This procedure was repeated with a further portion of $2.5 \mathrm{~mL}$ of HPLC grade methanol, bringing the mixture methanol plus residue at the same test tube. The methanol solution was filtered to vial (VertiPure PTFE Syringe, $13 \mathrm{~mm}$, $0.2 \mu \mathrm{m})$ and $25 \mu \mathrm{L}$ were injected into the chromatographic system.

\section{HPLC analysis of PEs extracts from supercritical $\mathrm{CO}_{2}$ process}

It was added $3 \mathrm{~mL}$ of HPLC grade methanol to the falcon tube containing the extract obtained by supercritical fluid extraction. The tube was mixed for 20 to 30 seconds and centrifuged at $9000 \mathrm{rpm}$ for 5 minutes. The clear supernatant was transferred to a $10 \mathrm{~mL}$ volumetric flask with the aid of micropipette. This procedure was repeated with two further portions of $3 \mathrm{~mL}$ of methanol, adding the methanolic extracts in the same $10 \mathrm{~mL}$ volumetric flask and completing the volume with methanol. The methanolic solution was filtered to vial (VertiPure PTFE Syringe, $13 \mathrm{~mm}, 0.2 \mu \mathrm{m}$ ) and $25 \mu \mathrm{L}$ were injected into the chromatographic system. A gradient of (A) phosphoric acid $0.1 \%(\mathrm{~V} / \mathrm{V})$ and $(\mathrm{B})$ acetonitrile was used as following described: start with $60 \%$ of B, increase B to $100 \%$ in the next 25 min, and keep $100 \%$ $\mathrm{B}$ for the next $3 \mathrm{~min}$. Then the column was washed with 2-propanol in the next $5 \mathrm{~min}$ and equilibrated with the starting conditions $(60 \%$ of B) for $10 \mathrm{~min}$. The chromatographic conditions were also adapted from Makkar et al. [21]. The PEs were analyzed and quantified by HPLC (Agilent) on a reverse phase C18 SB-C18 $250 \times 4.6 \mathrm{~mm}(5 \mu \mathrm{m})$, maintained at $40^{\circ} \mathrm{C}$.

Phorbol-12-myristate 13-acetate (PMA) was used as an external standard, which has a retention time around $23.5 \mathrm{~min}$. PEs peaks were integrated at $280 \mathrm{~nm}$, and the concentration was expressed as equivalent to PMA. The PEs peaks appeared between 17.5 and 21.5 $\mathrm{min}$. The percentage of PEs present in the extracts were calculated as a ratio between the areas of the PEs analysed in the supercritical extracts and the areas of PEs presented in the original cake. 


\section{Economic evaluation}

According Moraes, Zabot and Meireles [22], studies involving economic aspects are needed to transfer the knowledge acquired at laboratory/pilot scales to industrial scale. Many of them have simulated the manufacturing cost (MC) of extracts, mostly obtained by supercritical fluid extraction from vegetal raw materials and reported the financial viability of the process such as antioxidant extracts from Myrciaria cauliflor [23] and production of phenolic rich extracts and extraction of carotenoids from Brazilian plants [24,25].

Due to the fact that the technical feasibility of PEs extraction with supercritical carbon dioxide was assured and because of an absence of works using this type of raw material, an economic evaluation was done to predict the extraction behaviour of a process that will be conducted in a pilot scale of $42 \mathrm{~L}$, using the better operational conditions of temperature $\left(70^{\circ} \mathrm{C}\right)$ and pressure $(500 \mathrm{bar})$ obtained in the experimental unit, until the cake was considered detoxified. The scale up criterion adopted consisted in maintaining solvent mass to feed mass ratio (S/F) constant. The overall extraction curves obtained from laboratory scale experiments were used as reference, so that $\mathrm{S} / \mathrm{F}$ $=53.6$.

The commercial simulator SuperPro Designer v9.0 (Intelligen, Inc) was used to simulate the extraction process and to estimate the production cost of phorbol esters extracted with supercritical fluid until the cake was destoxified. This simulator has been used by other authors to simulate supercritical fluid extraction processes using different raw materials $[25,26]$. The method utilized by the software to estimate the manufacturing cost $[27,28]$ which uses the summation of the fixed cost of investment (FCI), the cost of utilities (CUT), the cost of labor (COL), the cost of raw material (CRM) and the cost of waste treatment (CWT) involved in the studied chemical process to compose the manufacturing cost.

The extraction process was simulated in a batch mode using a solidliquid extractor present in the database of the simulator. The scale-up criterion adopted consisted of maintaining a constant solvent to feed ratio (S/F). The cost of solid-liquid extractor of $42 \mathrm{~L}$ (size 2) of capacity was expressed by equation 2, based on the value US\$ 500.000 for extractor $50 \mathrm{~L}$ (size 1) provided by Prado [29], considering an annual depreciation rate of $10 \%$.

$$
\operatorname{Cost} 2=\operatorname{Cost} 1\left(\frac{\text { Size } 2}{\text { Size } 1}\right)^{0,6}
$$

The Jatropha cake press cost (US\$ 75/ton) was based on those reported by Sriram [30]. The cost of $\mathrm{CO}_{2}$ was considered US\$19.76/ $\mathrm{Kg}$ (White Martins) and it was adopted that the solvent can be recycled without further treatment. The utility cost was based from a simulation of the energy balance in SuperPro Designer: steam at US\$ 4.2/MT and the electricity at US\$ $0.092 / \mathrm{kWh}$. The revenue of the plant may consist of phorbol ester. The cost of phorbol ester was considered based on the reference price of phorbol 12-myristate 13 -acetate at US $\$ 212.85 / \mathrm{mg}$ [31]. This consideration was necessary due to the absence of this price in the literature.

\section{Results and Discussion}

The total yields, presented in equation 1, for each operational condition were shown in Table 2.

According to the results, the best yields were obtained at high pressures and the best extraction conditions were obtained at $70^{\circ} \mathrm{C}$ and pressure of 500 bar with the yield of $9.33 \%$. The accumulated yield in function of the extraction time of Jatropha cake can be seen in Figure 2. The extraction time was different from one condition to another according to the saturation of the raw material: 200 minutes for $98^{\circ} \mathrm{C}$ at $300 \mathrm{bar}, 300$ minutes for $70^{\circ} \mathrm{C}$ at $100 \mathrm{bar}, 90^{\circ} \mathrm{C}$ at $160 \mathrm{bar}, 40^{\circ} \mathrm{C}$ at 300 bar, $70^{\circ} \mathrm{C}$ at 500 bar and 400 minutes for $50^{\circ} \mathrm{C}$ and $160 \mathrm{bar}, 70^{\circ} \mathrm{C}$ at 300 bar, $50^{\circ} \mathrm{C}$ at 440 bar and $90^{\circ} \mathrm{C}$ at 440 bar.

It is important to note that Table 2 and Figure 3 show the total yield of the extraction, which not represents the PE yield for each operational condition. These behaviours cannot be represented because only the last fraction with the accumulated mass was analysed to know the quantity of PEs. It was observed that the yield increases with increasing pressure and higher pressures (300, 440 and 500 bar) had better yields when compared to lower ones (100 and $160 \mathrm{bar}$ ).

According to Figure 2, the increase in temperature, at constant pressure (300 bar), leads to an increase in yield. This may be related to the competitive effect of the vapor pressure of the solute and solvent density, due to the fact that when the vapor pressure of the solutes increased, the extraction process is favoured. At $160 \mathrm{bar}$, it was observed a cross-over behaviour between the curves of $50^{\circ} \mathrm{C}$ and $90^{\circ} \mathrm{C}$, showing the competitive effects of density and vapor pressure of the solute in the extraction efficiency.

The extracts obtained with supercritical extraction in different conditions were analysed to better quantify the content of PEs by HPLC and shown in Table 3.

The PE content in untreated seed cake was $1.97 \mathrm{mg} / \mathrm{g}$. This measure is the average of the HPLC analysis done in triplicate. Table 3 shows that the extraction at $70^{\circ} \mathrm{C}$ and 500 bar and $50^{\circ} \mathrm{C}$ and 440 bar were able to remove $22.19 \%$ and $23.03 \%$ of the PE present in the seed cake, respectively. The profile of the best condition of extraction $\left(70^{\circ} \mathrm{C}\right.$ and 500 bar) is shown in Figure 3 and indicates four peaks between retention times of 17 and 21.5 minutes, that represents the PE derivatives.

A central composite rotatable design (CCRD) was used to evaluate the PE yields extracted. The influence of the two variables (temperature and pressure) was statistically investigated at $95 \%$ of confidence level $(\mathrm{p} \leq 0.05)$. The linear and quadratic coefficients of the variables studied and their interactions, the standard error, the significance of each coefficient determined by the $\mathrm{p}$-value and the values of the analysis of variance (ANOVA) are listed in Table 4 . The p-values of the regression coefficients suggest that only pressure, as a linear factor, was significant $(\mathrm{p} \leq 0.05)$. This result corroborated the experimental results presented in Figure 3, in which the better operational conditions occurred at higher pressures. Moreover, the statistical analysis of the experimental data showed that the pressure had a significant effect on PE removal. A first order model was established (Equation 3) based on ANOVA which described the yield of PEs extracted as a function of the significant

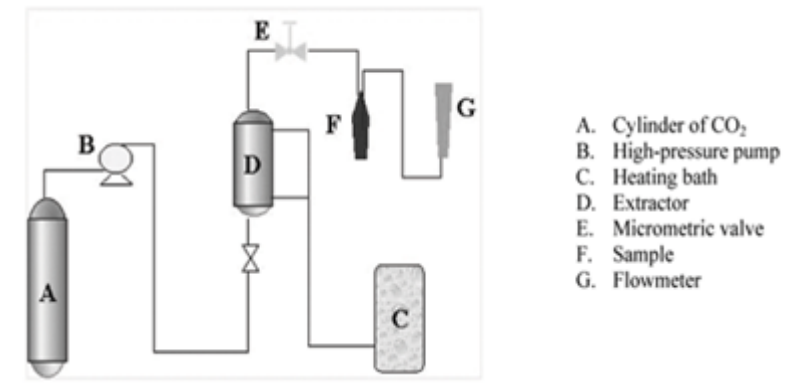

Figure 1: Flow sheet of experimental apparatus. 


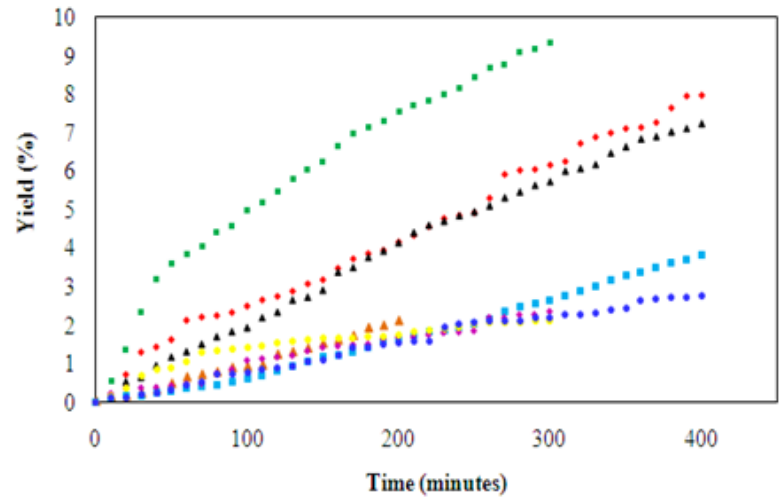

- $70^{\circ} \mathrm{C}-500 \mathrm{Bar} \quad \cdot 50^{\circ} \mathrm{C}-440 \mathrm{Bar} \quad .90^{\circ} \mathrm{C}-440 \mathrm{Bar} \quad 498^{\circ} \mathrm{C}-300 \mathrm{Bar}$ $=70^{\circ} \mathrm{C}-300 \mathrm{Bar} \quad+40^{\circ} \mathrm{C}-300 \mathrm{Bar} \quad 90^{\circ} \mathrm{C}-160 \mathrm{Bar} \quad \cdot 50^{\circ} \mathrm{C}-160 \mathrm{Bar}$

Figure 2: Extraction curves of Jatropha cake press with supercritical $\mathrm{CO}_{2}$.

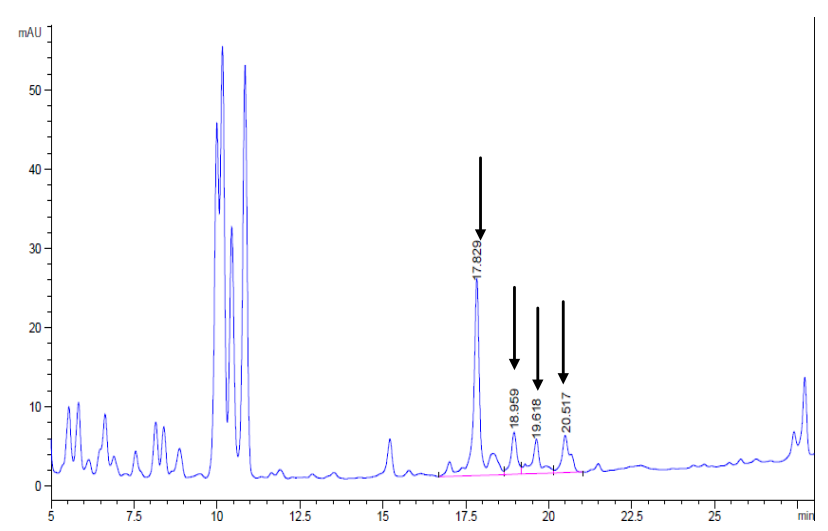

Figure 3: HPLC profile of the extract obtained at $70^{\circ} \mathrm{C}$ and 500 bar from Jatropha cake press.

independent variables (pressure).

$$
\mathrm{Y}=9.19+7.29 \mathrm{x}_{2}
$$

where $\mathrm{Y}$ is the yield of PEs and $\mathrm{x}_{2}$ is the pressure.

It was observed that the calculated $\mathrm{F}$ factor for the regression was greater than the tabulated one, demonstrating that the model is representative and, because of that, a response surface can be obtained.

Figure 4 shows the response surface illustrating the extraction yield as a function of temperature and pressure.

Analysing the response surface generated by the first order model, it be can observed an optimized region at higher pressures. The data indicated that, at any temperature, the yield of the extraction and consequently PEs concentration will increase with pressure increase.

The results of efficiency and temperature and pressure influences on the PEs extraction cannot be compared with another work, because until now, it was not found in the literature works concerning the extraction of PEs from Jatropha curcas cake with supercritical carbon dioxide to compare data.

As the phorbol ester content in untreated seed cake is $1.97 \mathrm{mg} / \mathrm{g}$ and the percentage extracted was $23 \%$, it can be concluded that the best operational condition $\left(500\right.$ bar and $70^{\circ} \mathrm{C}$ ) was not able to remove the phorbol esters to a tolerable level of $0.11 \mathrm{mg} / \mathrm{g}$ according to Makkar and Becker [32]. Due to that, it was simulated a supercritical extraction process involving more than one batch to assure the total extraction of PEs, based on the best operational conditions obtained in the experimental step.

\section{Economic evaluation}

The better condition of temperature and pressure (500 bar and $70^{\circ} \mathrm{C}$ ) was used to simulate the application of supercritical carbon dioxide in the PEs extraction until the cake was detoxified. A preliminary simulation using only one extractor was not sufficient and because of that, this study considered the industrial SFE containing 24 extractors (Figure 5), with a total of $7866 \mathrm{~h}$ of operation per year, cycle time of 60 hours which represents a total of $132 \mathrm{batch} / \mathrm{year}$. The experimental data corroborated the experimental data.

The annual throughput of phorbol ester was $2.47 \mathrm{~kg} / \mathrm{yr}$ and a concentration in PE of $0.11 \mathrm{mg} / \mathrm{g}$ could be reached with the simulation. The seed cake can be considered non-toxic with this level, confirming the efficiency of the methodology studied in this work.

Table 5 provides a summary of the overall material balances and material consumption of this process.

The direct fixed capital (DFC) refers to the fixed assets of an investment, such as plant and equipment. It is calculated at the process section level as the sum of direct, indirect and miscellaneous costs that are associated with a plant capital investment. The direct costs include cost elements that are directly related to an investment, such as the cost of equipment, process piping, instrumentation, buildings, facilities, etc. The indirect costs include costs that are indirectly related to an investment, such as the costs of engineering and construction. Additional costs such as the contractor's fee and contingencies are included in miscellaneous costs. In this study, the total DFC is around US\$ 98 million approximately and the individual cost items that contributed to the DFC are shown in Table 6.

Figure 6 shows the breakdown of the operating cost. The facility dependent cost is the most important item, accounting for $90 \%$ of the overall operating cost. In cases of designs, where there is no prior experience on the use of equipments, this is typically calculated as the sum of the costs associated with equipment maintenance, depreciation of the fixed capital cost, costs such as insurance, local taxes and possibly other overhead-type of factory expenses. Raw materials account for around $5.7 \%$ of the overall cost. Carbon dioxide is the most expensive raw material, accounting for $99.99 \%$ of the raw materials cost, comparing to the Jatropha press cake. Labour costs were based on the sum of the labour requirements for each unit procedure multiplied by a fixed labour rate (which was based on a basic labour rate, plus adjustments for fringe benefits, administration, and others). Supercritical fluid extraction is an environmentally safe technology, thus the cost of waste treatment was considered null.

Table 7 shows the results of the economic evaluation. For a plant of this capacity (42 L), the total capital investment is US $\$ 108,417,000$. Assuming a selling price of US\$212.85/mg, the project yields an aftertax internal rate of return (IRR) of $132.58 \%$ and a net present value (NPV) around US\$ 2 billion (assuming a discount interest of 7\%). The NPV is an indicator of how much value an investment adds to the industry. In this case, NPV is positive, what means that the investment would add value to the industry and therefore the project is economically viable and may be accepted and implemented. Based on these results, this project represents an attractive investment. It is 
Citation: Pereira CSS, Pessoa FLP, Mendonca S, Ribeiro JAA, Mendes MF (2015) Technical and Economic Evaluation of Phorbol Esters Extraction from Jatropha curcas Seed Cake using Supercritical Carbon Dioxide. J Adv Chem Eng 5: 132. doi:10.4172/2090-4568.1000132

Page 5 of 7

\begin{tabular}{|c|c|c|c|c|c|c|c|c|c|}
\hline $\begin{array}{c}\text { Operational } \\
\text { Conditions }\end{array}$ & $\begin{array}{c}70^{\circ} \mathrm{C} \\
100 \mathrm{bar}\end{array}$ & $50^{\circ} \mathrm{C} 160 \mathrm{bar}$ & $90^{\circ} \mathrm{C} 160 \mathrm{bar}$ & $40^{\circ} \mathrm{C} 300 \mathrm{bar}$ & $70^{\circ} \mathrm{C} 300$ bar & $98^{\circ} \mathrm{C} 300 \mathrm{bar}$ & $50^{\circ} \mathbf{C} 440$ bar & $90^{\circ} \mathrm{C} 440$ bar & $70^{\circ} \mathrm{C} 500 \mathrm{bar}$ \\
\hline Yield (\%) & 0.65 & 2.76 & 2.01 & 2.35 & 3.83 & 2.12 & 7.97 & 7.25 & 9.33 \\
\hline
\end{tabular}

Table 2: Yields of the extracts of Jatropha cake with supercritical $\mathrm{CO}_{2}$.

\begin{tabular}{|c|c|c|c|c|}
\hline Run & Temperature $\mathbf{~}^{\left.{ }^{\circ} \mathbf{C}\right)}$ & Pressure (bar) & PE (mg/g cake) & Yields PE (\%) \\
\hline 1 & 50 & 160 & 0.1639 & 8.32 \\
\hline 2 & 90 & 160 & 0.0508 & 2.58 \\
\hline 3 & 50 & 440 & 0.4536 & 23.03 \\
\hline 4 & 90 & 440 & 0.3812 & 19.35 \\
\hline 5 & 40 & 300 & 0.1761 & 8.94 \\
\hline 6 & 98 & 300 & 0.1057 & 5.36 \\
\hline 8 & 70 & 100 & 0.0640 & 3.25 \\
\hline 1 & 70 & 500 & 0.4370 & 22.19 \\
\hline 11 & 70 & 300 & 0.2230 & 11.32 \\
\hline & 70 & 300 & 0.1355 & 6.88 \\
\hline
\end{tabular}

Table 3: PEs yields from Jatropha cake extracted with supercritical $\mathrm{CO}_{2}$.

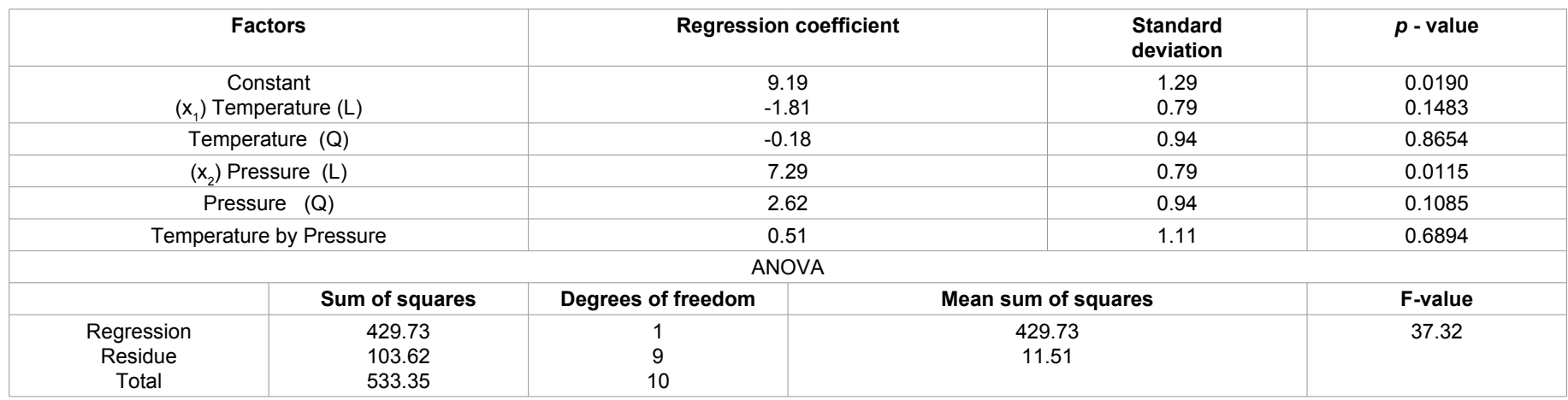

Table 4: Coefficients of regression of the CCRD and analysis of variance.

\begin{tabular}{|c|c|c|c|c|}
\hline Bulk Material & $\begin{array}{c}\text { Annual } \\
\text { Amount (kg) }\end{array}$ & $\mathbf{k g} /$ batch & $\begin{array}{c}\text { Unit Cost } \\
\text { (US\$) }\end{array}$ & $\begin{array}{c}\text { Annual Cost } \\
\text { (US\$) }\end{array}$ \\
\hline Carbon Dioxide & $70,831.00$ & 536.60 & 19.76 & $1,399,625.00$ \\
\hline Jatropha Cake & $1,320.00$ & 10.00 & 0.075 & 99.00 \\
\hline
\end{tabular}

Table 5: Overall Balance and Material Consumption.

\begin{tabular}{|c|c|c|}
\hline \multicolumn{3}{|c|}{ A. Total Plant Direct Cost (TPDC) } \\
\hline & 1. Equipment Purchase Cost & $13,009,000.00$ \\
\hline & 2. Installation & $6,361,000.00$ \\
\hline & 3. Process Piping & $4,033,000.00$ \\
\hline & 4. Instrumentation & $1,691,000.00$ \\
\hline & 5. Insulation & $390,000.00$ \\
\hline & 6. Electricals & $3,773,000.00$ \\
\hline & 7. Buildings & $781,000.00$ \\
\hline & $\begin{array}{l}\text { 8. Yard Improvement } \\
\text { 9. Auxiliary Facilities }\end{array}$ & $\begin{array}{l}1,301,000.00 \\
7,155,000.00\end{array}$ \\
\hline & TPDC & $38,494,000.00$ \\
\hline \multicolumn{3}{|c|}{ B. Total Plant Indirect Cost (TPIC) } \\
\hline & 10. Engineering & $12,318,000.00$ \\
\hline & 11. Construction & $13,088,000.00$ \\
\hline & TPIC & $25,406,000.00$ \\
\hline \multicolumn{3}{|c|}{ C. Total Plant Cost (TPC = TPDC + TPIC) } \\
\hline TPC & & $63,899,000.00$ \\
\hline \multicolumn{3}{|c|}{ D. Contractor's Fee and Contingency } \\
\hline & $\begin{array}{l}\text { 12. Contractor's Fee } \\
\text { 13. Contingency }\end{array}$ & $\begin{array}{l}11,502,000.00 \\
23,004,000.00\end{array}$ \\
\hline & CFC & $34,506,000.00$ \\
\hline \multicolumn{3}{|c|}{ E. Direct Fixed Capital Cost (DFC $=$ TPC + CFC) } \\
\hline DF & & $98,405,000.00$ \\
\hline
\end{tabular}

Table 6: Fixed capital estimate summary (2014 prices US\$). 


\begin{tabular}{|c|c|}
\hline Direct Fixed Cost & $98,405,000.00$ \\
\hline Total Investment (US $\$$ ) & $108,417,000.00$ \\
\hline Operating Cost (US $\$$ ) /yr & $24,572,000.00$ \\
\hline Total Revenues (US $\$$ ) /yr & $525,425,000.00$ \\
\hline Cost Basis Annual Rate mg ester/yr & $37,197.00$ \\
\hline Unit Production Cost USS/mg ester & 660.60 \\
\hline Gross Margin (\%) & 95.32 \\
\hline Return On Investment (\%) & 285.35 \\
\hline Payback Time (years) & 0.35 \\
\hline IRR After Taxes\% & 132.58 \\
\hline NPV at (7.00\%) US\$ & $2,094,841,000.00$ \\
\hline
\end{tabular}

Table 7: Key economic evaluation results.

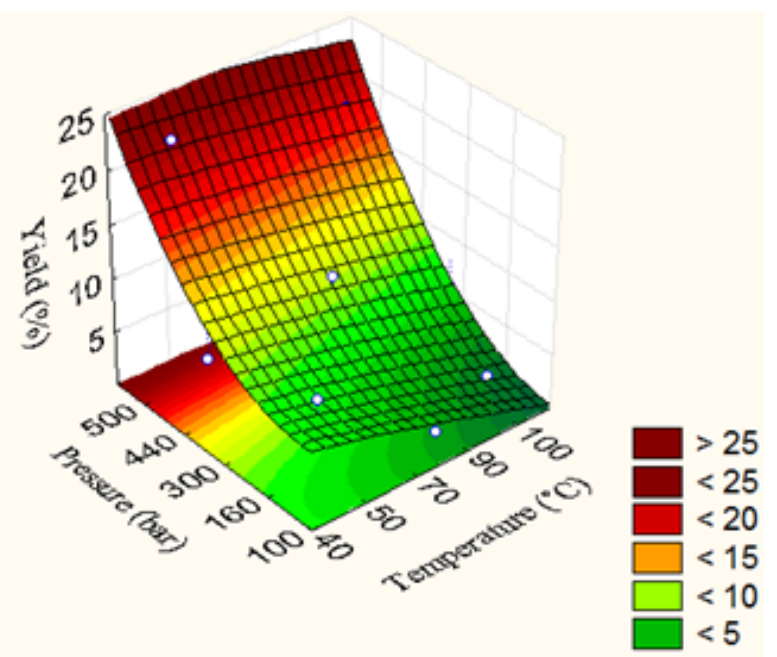

Figure 4: Response surface relating the PE concentration in function of temperature and pressure.

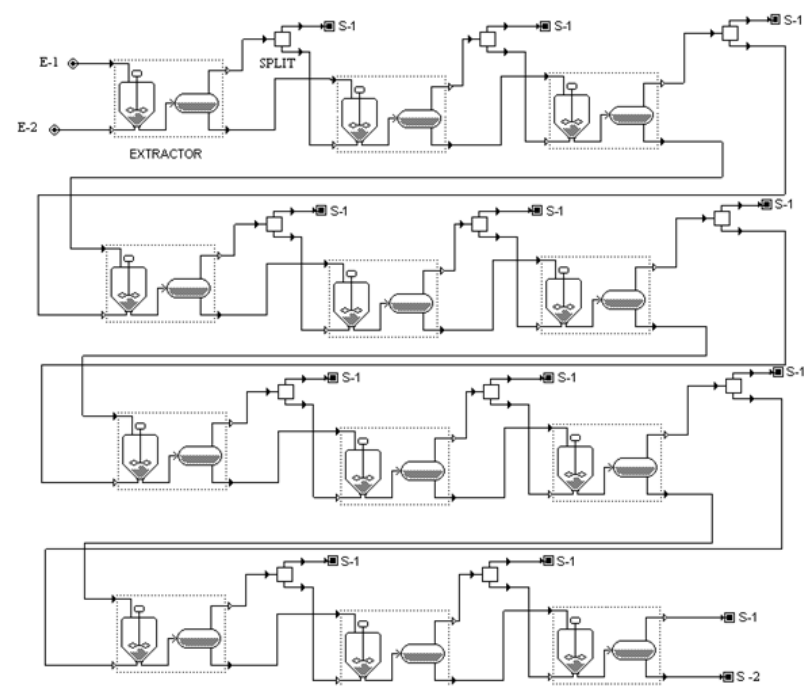

Figure 5: Process flowsheet built in Superpro Designer used for economic evaluation, E-1: Jatropha cake stream, E-2: $\mathrm{CO}_{2}$ stream, S-1: extract stream, and S-2: extract stream. important to note that this industrial plant can be used with other raw materials to extract different high aggregated components.

The analysis was based on the assumption that a new facility will be constructed for this process with a construction time of 30 months; start-up of 4 months and a 15 years project lifetime. The internal rate of return (IRR) is compared to the minimum attractive rate of return (MARR) or the cost of capital of the company. The decision criteria for accepting the project is to have an IRR greater than or equal to the minimum acceptable [20]. The criterion for evaluating the IRR in this study was that this is equal to or greater than $25 \%$ per year. A sensitivity study varying the selling price of phorbol ester in relation to total costs was conducted. The influences of the price in internal rate of return on total revenue and payback time are presented in Figure 7.

Figure 8 show the costs and profits in function of the rate of the production for phorbol ester. The break-even point was calculated in function of the direct fixed cost, variable costs and revenue. The breakeven point was situated in the figure at, approximately, $20 \%$ of the rate of production. It means that if the plant is operated above this rate of production, the profits are higher than the total costs of production.

The Superpro Designer was also used to simulate the operating cost of the cake using chemical treatment described by Guedes et al. [10], to compare the process costs. The detoxification of seed cake was obtained with soxhlet apparatus, reducing the PE content in $97.30 \%$ $(0.10 \mathrm{mg} / \mathrm{g})$ using methanol, extraction time of $8 \mathrm{hr}$ and solute/solvent ratio of 1:10 (w/v). Soxhlet simulation considered an industrial setup with three extractors of $42 \mathrm{~L}$. The results showed that the Soxhlet extraction presented lowest operating cost US\$ 16,195,000.00/yr

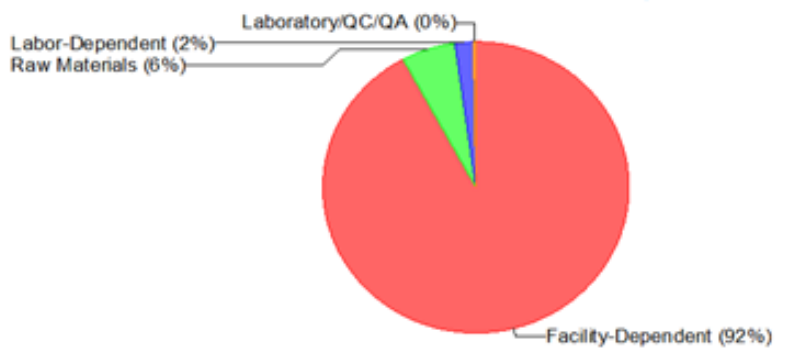

Figure 6: Breakdown of manufacturing cost for PEs extraction using supercritical $\mathrm{CO}_{2}$.

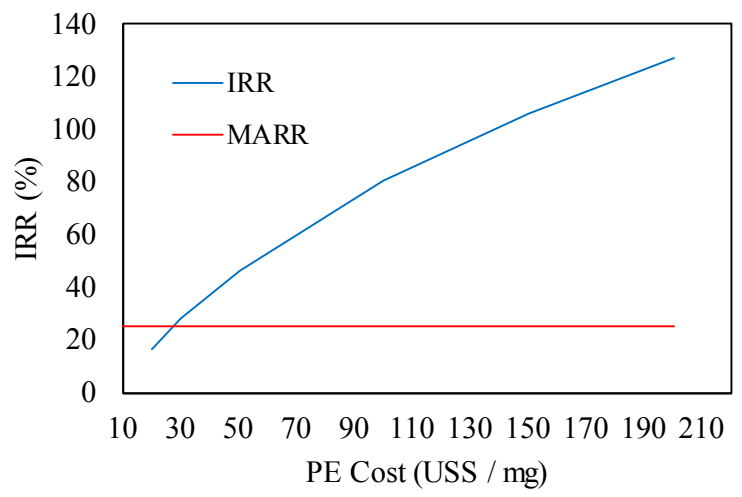

Figure 7: Influence of cost PE on the internal rate of return. 


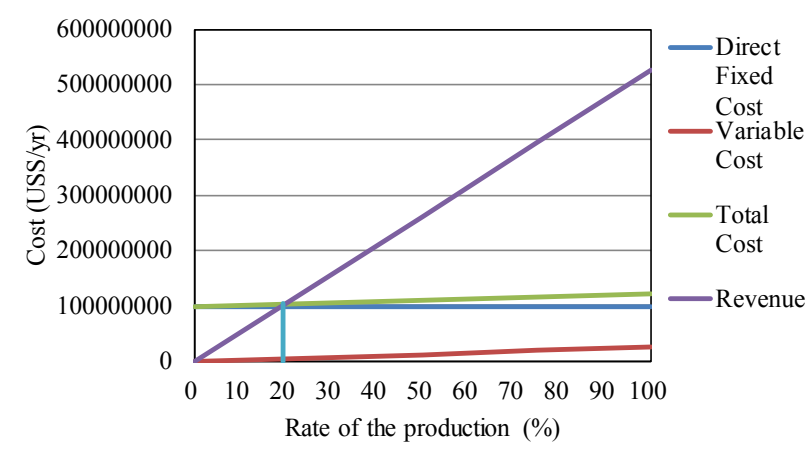

Figure 8: Variation of the costs and profit in function of the rate of the production of the plant.

compared with the operating cost of the supercritical fluid extraction (US\$ 24,572,000.00/yr). Probably, this behaviour is associated with the number of extractors used in the processes. On the other hand, the carbon dioxide in supercritical state is a promising solvent for green chemical processes due to its characteristics like non-toxicity, no flammability and non-explosiveness. Moreover, perhaps, it will be necessary more separation steps, using organic solvent, to eliminate the presence of solvent in the cake, able to be used in animal feed.

\section{Conclusion}

It was studied the technical evaluation of supercritical fluid to extract PEs from Jatropha curcas cake. The experiments were done applying a statistical experimental planning, showing that the best results occurred at $70^{\circ} \mathrm{C}$ and 500 bar with the yield of $9.33 \%$. It was observed that the yield increases with increasing pressure and a statistical analysis corroborated this behavior. The supercritical fluid extraction was very effective in the recuperation of the PE from Jatropha curcas cake around $23.0 \%$. The economic evaluation indicates that the process is economically viable and can be implemented to obtain detoxified cake and add value to phorbol ester.

\section{Acknowledgement}

The authors would like to thank Embrapa Agroenergy (Brasilia, Brazil), for the analysis and FAPERJ for the financial support.

\section{References}

1. Ceasar SA, Ignacimuthu S (2011) Applications of biotechnology and biochemical engineering for the development of Jatropha and biodiesel: a review. Renew Sustain Energy Rev 15: 5176-5185.

2. Kootstra AMJ, Beeftink HH, Scott ES, Sanders JPM (2011) Valorization of Jatropha curcas: solubilization of proteins and sugars from the $\mathrm{NaOH}$ extracted de-oiled press cake. Industrial Crops and Products 34: 972-978.

3. Herrera JM, Martinez CJ, Ayala AM, Siciliano LG, Escobedo RM, et al. (2012) Evaluation of the Nutritional Quality of Nontoxic Kernel Flour From Jatropha Curcas in rats. J Food Qual 35: 152-158.

4. Makkar HPS, Becker K, Sporer F, Wink M (1997) Studies of nutritive potential and toxic constituents of different provenances of Jatropha curcas. J Agric Food Chem 45: 3152-3157.

5. Haas W, Sterk H, Mittelbach M (2002) Novel 12-deoxy-16-hydroxyphorbol diesters isolated from the seed oil of Jatropha curcas. J Nat Prod 65: 1434-1440.

6. Devappa RK, Makkar HPS, Becker K (2010) Optimization of conditions for the extraction of phorbol esters from Jatropha oil. Biomass Bioenergy 34: 11251133.

7. Joshi C, Mathur P, Khare SK (2011) Degradation of phorbol esters by Pseudomonas aeruginosa PseA during solid-state fermentation of deoiled Jatropha curcas seed cake. Bioresour Technol 102: 4815-4819.

8. Xiao J, Zhang H, Niu L, Wang X, Lu X (2011) Evaluation of detoxification methods on toxic and antinutritional composition and nutritional quality of proteins in Jatropha curcas meal. J Agric Food Chem 59: 4040-4044.

9. Phasukarratchai N, Tontayakom V, Tongcumpou C (2012) Reduction of phorbol esters in Jatropha curcas $L$. pressed meal by surfactant solutions extraction. Biomass and Bioenergy 45: 48-56.

10. Guedes RE, Cruz FDA, Lima MCD, Sant'Ana LDO, Castro RN, et al. (2014) Detoxification of Jatropha curcas seed cake using chemical treatment: Analysis with a central composite rotatable design. Industrial Crops and Products 52: 537-543.

11. Joshi C, Khare SK (2011) Utilization of deoiled Jatropha curcas seed cake for production of xylanase from thermophilic Scytalidium thermophilum. Bioresour Technol 102: 1722-1726.

12. Devappa RK, Malakar CC, Makkar HP, Becker K (2013) Pharmaceutical potential of phorbol esters from Jatropha curcas oil. Nat Prod Res 27: 1459-1462.

13. Roach JS, Devappa RK, Makkar HP, Becker K (2012) Isolation, stability and bioactivity of Jatropha curcas phorbol esters. Fitoterapia 83: 586-592.

14. Wender PA, Kee JM, Warrington JM (2008) Practical synthesis of prostratin DPP, and their analogs, adjuvant leads against latent HIV. Science 320: 649-652.

15. Devappa RK, Angulo-Escalante MA, Makkar HPS, Becker K (2012) Potential of using phorbol esters as an insecticide against Spodoptera frugiperda. Industrial Crops and Products 38: 50-53.

16. Aregheore EM, Becker K, Makkar HPS (2003) Detoxification of a toxic variety of jatropha curcas using heat and chemical treatments, and preliminary nutritional evaluation with rats. South Pac J Nat Sci 21: 51-56.

17. Martinez-Herrera J, Siddhuraju P, Francis G, Davila-Ortiz G, Becker K (2006) Chemical composition, toxic/antimetabolite constituents, and effects of different treatments on their levels, in four provenances of Jatropha curcas $L$ from Mexico. Food Chem 96: 80-89.

18. Machida H, Takesue M, Smith Jr RL (2011) Green chemical processes with supercritical fluids: Properties, materials, separations and energy. The Journal of Supercritical Fluids 60: 2-15.

19. Brunner G (1994) Gas extraction: an introduction to fundamentals of supercritical fluids and the application to separation process.

20. Mendes MF, Pessoa FLP, Uller AMC (2005) Optimization of the process of concentration of vitamin $\mathrm{E}$ from DDSO using supercritical $\mathrm{CO}_{2}$. Brazilian Journal of Chemical Engineering 22: 83.

21. Makkar H, Maes J, De Greyt W, Becker K (2009) Removal and degradation of phorbol esters during pre-treatment and transesterification of Jatropha curcas oil. Journal of the American Oil Chemists' Society 86: 173-181.

22. Moraes MN, Zabot GL, Meireles MAA (2014) Applications of Supercritical Fluids in Latin America: Past, Present and Future Trends. Food and Public Health 4: 162-179.

23. Cavalcanti VMS, Aznar M, Melo SAV, Cruz FG (2013) Economic evaluation based on an experimental study of extraction of alkylamides from Spilanthes genera using supercritical $\mathrm{CO}_{2}$. In: 10th Conference on Supercritical Fluids and Their Applications 1: 476

24. Prado JM, Assis AR, Maróstica-Júnior MR, Meireles MAA (2010) Manufacturing cost of supercritical-extracted oils and carotenoids from amazonian plants. $J$ Food Process Eng 33: 348-369.

25. Prado JM, Dalmolin I, Carareto NDD, Basso RC, Meirelles AJA, et al. (2012) Supercritical fluid extraction of grape seed: process scale-up, extract chemical composition and economic evaluation. J Food Engineering 109: 249-257.

26. Delgado B, Pessoa FLP (2014) Simulation of butanol production by an integrated fermentation process using supercritical fluid extraction with carbon dioxide. New Biotechnology.

27. Peters MS, Timmerhaus KD (1991) Plant design and economics for chemical engineers. McGraw-Hill, USA.

28. Turton R, Bailie RC, Whiting WB, Shaeiwitz JA (2003) Analysis, Synthesis, and Design of Chemical Processes. Prentice Hall, USA.

29. Prado IM, Albuquerque CLC, Cavalcanti RN, Meireles MAA (2009) Use of commercial process simulator to estimate the cost of manufacturing (COM) of carotenoids obtained via supercritical technology from palm and buriti trees. 9th International Symposium on Supercritical Fluids, Arcachon, France.

30. Sriram S (2012) Potential of New Jatropha Varieties.

31. Sigma Aldrich.

32. Makkar HP, Becker K (1999) Nutritional studies on rats and fish (carp Cyprinus carpio) fed diets containing unheated and heated Jatropha curcas meal of a non-toxic provenance. Plant Foods Hum Nutr 53: 183-192. 